Journal of Engineering and Applied Sciences 15 (1): 7-9, 2020

ISSN: 1816-949X

(C) Medwell Journals, 2020

\title{
Implementation of Mobile Learning with Ethnomatematic Models on Geometry Course in University
}

\author{
Lusi Rachmiazasi Masduki, Suparman and Edi Prayitno \\ Universitas Terbuka Semarang, Central Java, Indonesia
}

\begin{abstract}
This advanced research aims to determine the feasibility, effectiveness and practicality of mobile math products in geometry courses an expanded manner in LPTKs in Central Java. This research method uses the Borg and Gall development Model with 10 stages that's are; research and information collecting, planning, develop preliminary form of product, preliminary field testing, main product revision, main field testing, operational product revision, operational field testing, final product revision, dissemination and implementation. In this follow-up study using steps 7-10 with the produced mobile math products have been tested expanded. The mobile math products obtained from students and lecturers responses with the average percentage of student responses, namely the media aspect by $90 \%$, material aspects by $90 \%$, language and display aspects by $86 \%$ and examples of questions and exercises by $93 \%$, its means that students generally, assess this product as valid and practical to use in classroom learning while the results of the average percentage of lecturer responses are media aspects by $100 \%$, material aspects by $100 \%$, language and appearance aspects by $97 \%$ and sample problem aspects and training by $100 \%$ means that the lecturer in general considers this product to be very valid and practical to use in geometry learning in the class then the post test results obtained by the average value of the experimental class better than the control class are $78.33>60.66$ and $t$ count $<t$ table is $1.28<1.65$, so that, this product is effectively used as a medium of learning mathematics for the mathematics education Walisongo State Islamic University Semarang.
\end{abstract}

Key words: Mobile learning, ethnomatematics, geometry, learning, mathematics, post test

\section{INTRODUCTION}

The previous study was obtained data that produced mobile learning prototypes in geometry courses that were feasible to use according to expert validation then from the post test results in a limited test in the open university mathematics education study program obtained average student scores with average 60 mobile learning products at geometry courses have not helped students in mastering the material thoroughly while based on the student response questionnaire data shows that more than $85 \%$ of students are enthusiastic and motivated in using mobile learning media in the learning process because mobile learning applications are designed for all types of smart phones and are easy to use.

Development research according to Borg and Gall development steps covering 10 steps, steps 1-6 have produced mobile math products that are suitable for use in the learning process according to lecturer and students at open university while for steps 7-10 are (7) Design revision (8) Usage testing (9) Product revision (10) Mass production will be carried out an expanded trial di mathematics education program at UIN Walisongo Semarang with hope that product can increase student motivation and learning outcomes anytime and anywhere. Media learning are suitable and easily accessible by open university students is mobile media this is because mobile media can be accessed anytime and anywhere, mobile learning research conducted by Barker et al. (2005), shows that m-Learning has been used in several European countries because learning that is usually face to face becomes more flexible in time and place. This is reinforced by research conducted by Gayeski (2002) which shows that learning through the development of mobile applications can improve student performance. This is in accordance with the research by Hill and Roldan (2005) which shows that learning with mobile can improve collaboration between fellow users and facilitate communication with their environment. This is in accordance with the research by Ismail et al. (2010) which shows that more than $50 \%$ of Universiti Sains Malaysia students are very enthusiastic in using the learning mobile application because applications are easily accessed and used everywhere.

Based on the description problem can be formulated as follows: how to develop mobile learning media in the geometry subject with an ethnomatematics model that is able to attract students interest and learning motivation at Walisongo State Islamic University Semarang? And can learning using mobile learning with ethnomatematics models be effective and practical? Based on the above problems, further research has been carried out effectively and efficiently extensively on the dissemination and implementation of mobile learning applications with ethnomatematics models in the geometry course.

Corresponding Author: Lusi Rachmiazasi Masduki, Universitas Terbuka Semarang, Central Java, Indonesia 


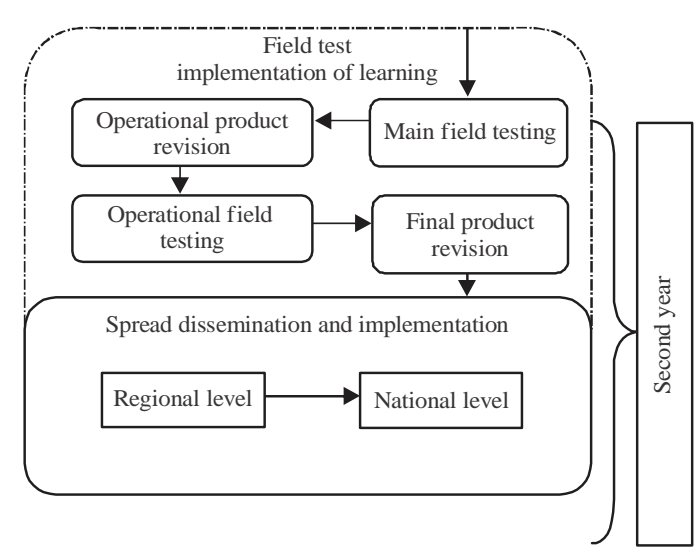

Fig. 1: Research scheme for the development of Borg and Gall

\section{MATERIALS AND METHODS}

This research includes the type of R\&D (Research and Development) or the type of development research using a model developed by Borg and Gall. In this study, includes stage (7) operational product revision which is carried out in an integrated manner where the activity at this stage is a trial draft 2 involving 9 classes. This trial was conducted to find out whether draft 2 had shown a performance as expected. If there are still weaknesses then the stage is carried out (8) operational field testing is an improvement in draft 2 to analyze weaknesses based on the results of the expanded trial. The next step is (9) final product revision that produces a revised draft 2 . The results of the improvement from draft 2 are then called the final draft that is ready to be published. The final stage of this research is (10) dissemination and implementation. This stage is pursued with aim that the newly developed product can be used by the wider community. The core activity in this stage is to implement of mobile learning with ethnomatematic models on geometry course in university. The research procedure that adopts the 10 stages of development of Borg and Gall can be seen in Fig. 1.

\section{RESULTS AND DISCUSSION}

Results of the average percentage of students and lecturers responses, namely the media aspect by $90 \%$, material aspects by $90 \%$, language and display aspects by $86 \%$ and examples of questions and exercises by $93 \%$, its means that students generally, assess this product as valid and practical to use in classroom learning (Fig. 2).

The results of the average percentage of lecturer responses are media aspects by $100 \%$, material aspects by $100 \%$, language and appearance aspects by $97 \%$ and sample problem aspects and training by $100 \%$ means that the lecturer in general considers this product to be very valid and practical to use in geometry learning in the class (Fig. 3).

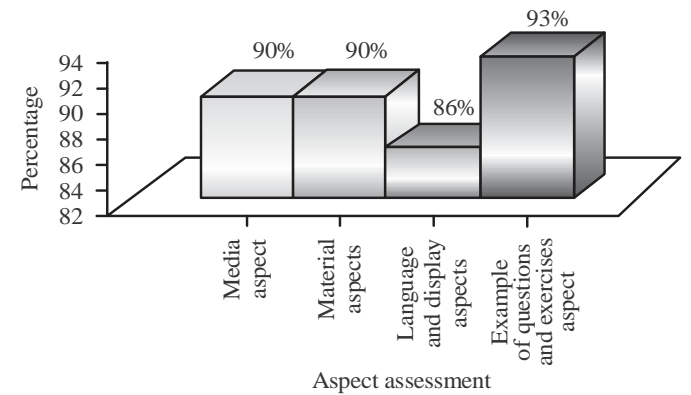

Fig. 2: Percentage of response students UIN Walisongo Semarang

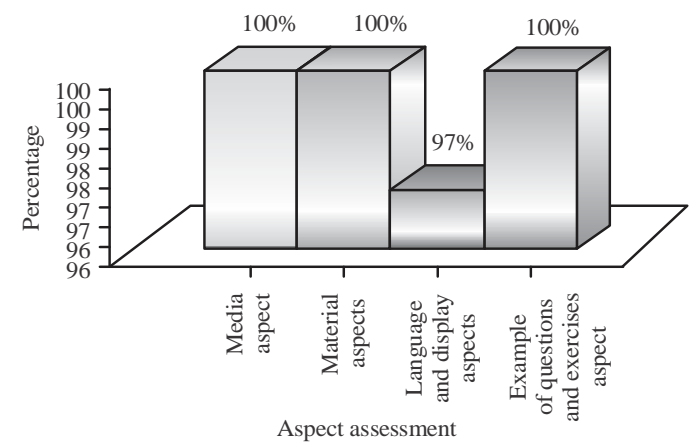

Fig. 3: Percentage of response lecturer UIN Walisongo Semarang

Based on the posttest results in UIN Walisongo Semarang, the posttest results obtained showed that the average value of the experimental class was better than the control class $78.33>60.66$ and $t$ count $<\mathrm{t}$ table which was $1.28<1.65$, so that, this product was effectively used as mathematics learning media for UIN Walisongo Semarang.

\section{CONCLUSION}

Students generally, value this product as valid and practical for use in classroom learning. While lecturer in general considered this product very valid and practical to be used in the study of geometry learning in the classroom. This product is effectively as a medium of mathematics learning for mathematics education programs at UIN Walisongo Semarang.

\section{REFERENCES}

Barker, A., G. Krull and B. Mallinson, 2005. A proposed theoretical model for m-Learning adoption in developing countries. Proceedings of the 4th World Conference on m-Learning, October 25-28, 2005, Cape Town, South Africa, pp: 1-10.

Gayeski, D.M., 2002. Learning Unplugged: Using Mobile Technologies for Organizational Training and Performance Improvement. 1st Edn., AMACOM, USA., Pages: 192. 


\section{J. Eng. Applied Sci., 15 (1): 7-9, 2020}

Hill, T.R. and M. Roldan, 2005. Toward third generation threaded discussions for mobile learning: Opportunities and challenges for ubiquitous collaborative environments. Inf. Syst. Front., 7: 55-70.
Ismail, I., T. Gunasegaran, P.P. Koh and R.M. Idrus, 2010. Satisfaction of distance learners towards mobile learning in the Universiti Sains Malaysia. Malaysian J. Educ. Technol., 10: 47-54. 